\title{
Marriage considerations in sending girls to school in Bangladesh: Some qualitative evidence
}

\author{
Sajeda Amin \\ Population Council \\ Lopita Huq
}

Follow this and additional works at: https://knowledgecommons.popcouncil.org/departments_sbsr-pgy

Part of the Demography, Population, and Ecology Commons, Family, Life Course, and Society Commons, Gender and Sexuality Commons, Gender Equity in Education Commons, and the International Public Health Commons

How does access to this work benefit you? Let us know!

\section{Recommended Citation}

Amin, Sajeda and Lopita Huq. 2008. "Marriage considerations in sending girls to school in Bangladesh: Some qualitative evidence," Poverty, Gender, and Youth Working Paper no. 12. New York: Population Council. 


\section{POVERTY, GENDER, AND YOUTH}

\section{Marriage Considerations in Sending Girls to School in Bangladesh: Some Qualitative Evidence}

Sajeda Amin and Lopita Huq

WORKING PAPER NO. 122008 


\section{(1) Population Council}

One Dag Hammarskjold Plaza

New York, New York 10017 USA

www.popcouncil.org

pubinfo@popcouncil.org

For information on Poverty, Gender, and Youth working papers, see www.popcouncil.org/publications/wp/index.html

This material may not be reproduced without written permission from the authors.

ISSN: $1554-8538$

(C) 2008 The Population Council, Inc. 


\title{
Marriage Considerations in Sending Girls to School in Bangladesh: Some Qualitative Evidence
}

\author{
Sajeda Amin \\ Lopita Huq
}

Sajeda Amin is Senior Associate, Program on Poverty, Gender, and Youth, Population Council, New York. E-mail: samin@ popcouncil.org. Lopita Huq is Consultant, Population Council, New York.

This paper was made possible through support provided by the Department for International Development, U.K. (DfID); the Hewlett Foundation (\#2005-6492 and 20011124); the Mellon Foundation; UNICEF, Dhaka; and the Office of Population and Reproductive Health, Bureau for Global Health, U.S. Agency for International Development, under the terms of Award No. HRN-A-00-99-00010. The opinions expressed herein are those of the authors and do not necessarily reflect the views of the U.S. Agency for International Development. 


\begin{abstract}
This paper analyzes parents' decisions about girls' schooling in the context of marriage through in-depth exploration of case studies in two rural areas of northern Bangladesh. The villages are sites of a long-term community study from 1991 and 2002, a time when significant changes were underway, partly as a result of new school incentive programs introduced in 1994. The data show that the rise of dowry demands, a relatively recent practice that is barely a generation old among Muslims in these areas, asserts an important and independent influence on marriage decisions and indirectly influences decisions about schooling. The influence of programs such as secondary school scholarships for girls is best viewed in the context of familial concerns about marriage and dowry.
\end{abstract}


Several indicators of educational attainment suggest that significant changes related to schooling have taken place in Bangladesh. Starting at very low levels at the time Bangladesh became independent in 1971, primary education is now universal, with a school in every village. Secondary school attendance is also high. The data suggest that mass education is now established in Bangladesh.

Marriage market dynamics have also changed. A well-documented rise has occurred in the practice of dowry - payments by a bride's family to the groom or his family — and a considerable inflation is seen in dowry demands, replacing a custom of bride price, the flow of payments in the opposite direction. The phenomenon is relatively recent in Bangladesh and mimics trends described throughout India among groups that did not traditionally practice dowry, such as lower caste Hindus in the north and Hindus in the south Indian state of Karnataka (Sharma 1980; Rao 1993a, 1993b). The first dowry payments in the Bangladeshi villages we study in this paper were reported around the 1960s (Amin and Cain 1997). The practice of dowry was made illegal by a law passed in 1985 by the Government of Bangladesh.

Rapid schooling changes, beginning in the late 1980s and early 1990s, took place somewhat later than the rise of dowry. Girls' school attendance rose faster than boys', and there is now near gender equity in the first ten years of school (World Bank 2008). These changes likely are attributable to programs and policies in the education sector that attempt to close the gender gap. These have included enrollment drives that target girls, free tuition for girls while boys are required to pay, and, most recently, monetary incentive programs that reward families for sending girls to and keeping them in secondary school. These incentive programs are especially aimed at raising age at marriage by promoting continued education and thereby encouraging later marriages and in turn lower fertility. One requirement of the programs is that parents sign a pledge that they will not marry off their enrolled daughters before 18 years of age.

There is compelling evidence, nevertheless, that the persistence of early marriage poses a critical challenge to ensuring full gender equity in education. Girls drop out at a faster rate than boys after the tenth year of school (Mahmud and Amin 2006). A recent survey of adolescents shows that only 10 percent of girls who completed primary school passed the secondary school certificate examination compared to 25 percent of boys (Bangladesh Adolescent Survey, authors' calculation). Two recent papers explore how marriage decisions about school dropout for girls vary with household economic status. Girls in wealthier families are more likely to drop out because of marriage, while poor girls drop out for other reasons (Mahmud and Amin 2006). Schuler and colleagues (2006) examine qualitative evidence of divergent marriage strategies for the poor and wealthy in rural Bangladesh and suggest that norms favoring early marriage are eroding faster among wealthy families because of changing gender ideals and aspirations.

This paper explores the interrelationships between education and the timing and quality of marriage, including prospects for marriage, the "price" of husbands, and the influence of monetary incentives on the timing of marriage. The data come from an intensive study conducted in two villages in Mohanpur thana located in Rajshahi district in northwest Bangladesh. Like the rest of rural Bangladesh, the two villages are agro-based, largely Muslim communities and have 
experienced considerable social and demographic change in education, family planning services, women's development programs, and child health services.

\section{BACKGROUND}

Education can affect women's lives through multiple pathways in which marriage can play a key mediating role. Studies from contemporary South Asian societies show that education may improve women's bargaining position as a valued marriage market attribute (Rao 1993b); it may facilitate delay in marriage by giving women a legitimate reason to remain single after puberty (Amin 1996); education may increase women's autonomy by giving them a greater decisionmaking role within the natal family and allowing them to articulate their preferences about marriage, including when and whom to marry (Mason 1984; Jejeebhoy 1995); and education can provide married women with negotiating skills or bargaining power within the conjugal relationship (Sathar 1996).

Most studies of education's influence on changes in women's status have taken place in contexts where educational gains occurred for boys as well as for girls. Exploring data from Bangladesh for a time period preceding the gender-differentiated schooling interventions of the 1990s, Amin and Lloyd (2002) found that spousal gender gaps remained rigid even as overall levels of women's education rose. There have been few evaluations of the influence of rising education for girls relative to boys because reduction in the gender gap in education is a recent phenomenon in Bangladesh and other developing countries (NRC 2005). One exception is a World Bank survey conduct in 2006 in Bangladesh showing that married women born between 1981 and 1991 are more likely to marry men with less education than themselves relative to women born between 1946 and 1961 (World Bank 2008).

Recent work on India and Bangladesh explores the specific question of interest in this paper, namely how education affects marriage market dynamics (Rao 1993a, 1993b; Edlund 2000). Behrman and colleagues (1999) examine more far-reaching outcomes of marriage by looking at the implications of spousal characteristics for child welfare. Hallman (2000) follows a similar approach.

While the literature has been informative in many ways, there is disagreement about how education affects the prospects for marriage or the price paid for husbands. Rao (1993b) and Behrman et al. (1999) suggest that education substitutes for dowry, whereas Edlund (2000) and Hallman (2000) provide evidence to support the premise that education complements dowry, thus reducing the amounts paid. Our own assessment is premised on the notion that some of the disagreement in the literature may be resolved through a more nuanced understanding of the process of marriage negotiations. The methodology is descriptive and relies primarily on qualitative evidence.

We take into account the notion that perceptions about the marriage market may be as important as the realities themselves. Kabeer (2001) suggests that the concept of "habitus" used by Bourdieu to "capture the socially structured subjectivity in social practice" is appropriate in this context. In Bangladesh, behavior, practice, and aspirations are accommodated within a set of objective possibilities offered by the social context and are governed by the community's code of 
conduct. However, this does not preclude the role of agency, as is suggested by our emphasis on social and cultural structures. Rather individuals operate within the habitus and seek to maximize their interests while adhering to the rules and norms of society. In this context agency becomes more closely associated with the interpretation of rules, and individual interests determine how the rules are interpreted. Thus even while working within a given framework, the self-interested interpretation of rules and the deployment of strategies to serve those interests give rise to a diversity of outcomes. As long as these behaviors and strategies are accommodated within the "sense of limits" invoked by the habitus, no change in the social order can be expected.

\section{METHOD AND DATA}

We address these issues through in-depth case studies of recent marriages, with a focus on the details of the marriage process. In the study area the process consists of the receipt of marriage proposals, marriage negotiations including agreement on amount of dowry, and the events immediately preceding and following the marriage. Case studies are based on interviews with married and unmarried young women and available members of her family and her husband's family. The interviews focus on issues pertaining to education and schooling, particularly as they are discussed in the context of marriage. Our experience with gathering information on education has shown that values and attitudes that appear relatively vague in general discussions tend to come into sharper focus in the context of marriage.

The case studies have been selected from an earlier detailed census of the villages conducted in 2000 as part of a long-term research program that began in 1991. All households that include marriageable or newly married girls (aged 12 to 24) were stratified in three categories of 1) newly married, 2) secondary school-going, and 3) primary school-going girls in class four and five from over 800 households covered in the census. These categories were chosen based on our observation that these were ages when girls were considered to be eligible for marriage. Almost all girls in the marriageable age range were either in school or married. The case studies were then selected through random sampling of the selected households. In-depth interviews were conducted with the respondents and with key informants in two rounds. The interviews were based on an extensive open-ended guideline covering personal information, issues of marriage including dowry, educational experiences, present circumstances, and perceptions and attitudes.

In addition to the qualitative data, we make use of census data on marriage and education, as well as a detailed survey of children and adolescents conducted in 1991, 1995, and 2001 that provides data on education and marriage for all households in the study area.

\section{RESULTS}

We begin with some quantitative evidence from the study area on the associations between age at marriage, dowry, and education. This is followed by a presentation of the qualitative data on marriage, where we describe the "habitus," or context, as reflected in perceptions of marriage market dynamics and the factors that affect it. Then we present evidence on the role of agency as it applies to marriage strategies and investments in education. 
A slight decline has been seen in the overall proportion of girls who are married at early ages. According to the 1992 census, 36 percent of girls aged 11-19 were married. This percentage fell to 32 percent in 1995 and 28 percent in 2000. Thus, the trend toward delayed marriage appears to have been sustained and is possibly associated with rising education. Compared to the immense changes in schooling, however, the trend in delayed marriage is minimal. Figure 1 shows trends in schooling attainment relative to the proportion of girls remaining single (never married) in the relevant age range from census data collected in 1992, 1995, and 2000. Impressive improvement has taken place in the proportions of girls enrolled in school: the percentage of adolescent girls who finished primary school increased from 22 percent in 1992 to 71 percent in 2000. The proportion of girls attending secondary school rose from 10 percent to 49 percent over the same period. The relative gradient of primary school completion and secondary school attendance indicators is far steeper than the modestly rising trend in proportions single.

Figure 1 Proportion of girls single, completed primary and attending secondary school in study area, 1992-2000

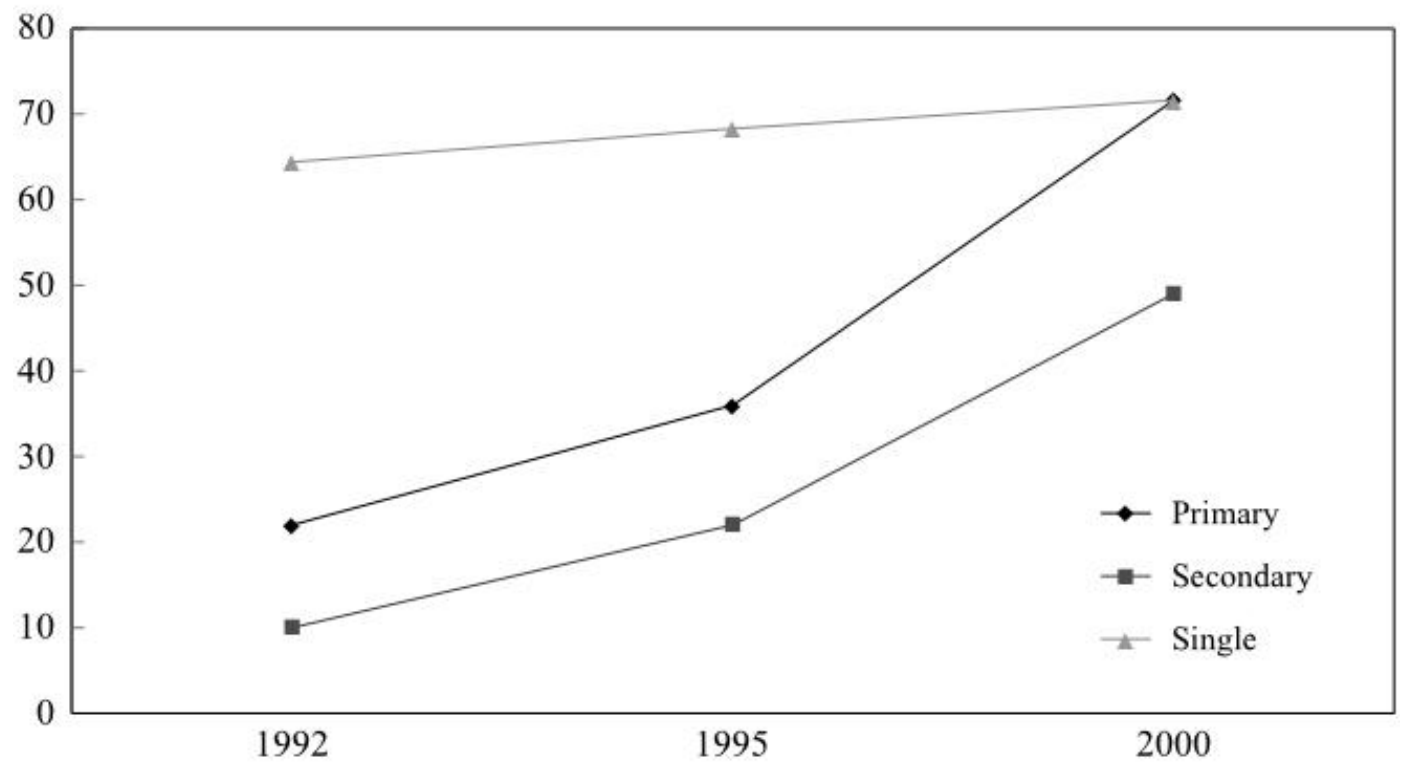

Among girls who have completed primary school, the propensity is to continue in school until marriage. In the past the tendency among these girls would have been either to marry or to remain at home rather than continue in school or work outside the home.

Data on marriage and dowry used here are restricted to adolescents reported to be between ages 12 and $19 .{ }^{1}$ Seventy percent of all marriages in our study involved a dowry payment, with the average amount reported as Tk. 10,964, or about US\$220 in 2000. Both the proportion of marriages with dowry and the amount of dowry reported in 2000 are comparable to figures reported a decade earlier (1991) for women of the same age range (Amin 1996). These figures are also in general 
agreement with a study conducted by the authors that included nearby Chapainawabganj district (Amin, Mahmud, and Huq 2002), as well as with figures from a nationally representative adolescent survey conducted in 2005.

Table 1 explores the determinants of marriage payments according to characteristics of the bride. Bivariate and multivariate associations were assessed between dowry, age at marriage, marriage distance, and level of education. Since both associations follow the same pattern, we report only the bivariate associations for simplicity. Dowry payment rises with age at marriage, marriage distance, and level of education. While a relatively small proportion of girls with higher education pay dowry for their marriage, 39 percent as opposed to 79 percent of girls with less than primary school education, those who do pay dowry pay a much larger amount. This apparently contradictory nature of dowry payments, where higher education can result either in a much higher dowry or in no dowry at all, is explored further below.

Table 1 Dowry payment by selected bride characteristics, Mohanpur village study 2000

\begin{tabular}{lcr}
\hline Variable & $\begin{array}{c}\text { Percent who paid dowry } \\
\text { at marriage }(\mathbf{N})\end{array}$ & $\begin{array}{c}\text { Average dowry paid } \\
\text { (Taka) }(\mathbf{N})\end{array}$ \\
\hline $\begin{array}{l}\text { Marriage distance } \\
\text { Married outside village }\end{array}$ & $73(86)$ & $11,898(63)$ \\
$\quad$ Married in village & $67(39)$ & $8,701(26)$ \\
Level of education of bride & $79(63)$ & $9,323(50)$ \\
Less than primary & $39(62)$ & $13,069(62)$ \\
Primary or greater & $63(24)$ & $9,406(15)$ \\
Age at marriage of bride & $75(72)$ & $9,560(54)$ \\
Less than 15 & $69(29)$ & $15,925(20)$ \\
15 to 16 & & \\
17 to 19 & &
\end{tabular}

US\$1= Tk. 50 in 2000.

\section{The Social ConTeXt OR "HaBitus"}

We turn now to our qualitative data on marriage. As a general rule, respondents were married at very young ages, and, consistent with the census data, most were attending secondary school just prior to or at the time of marriage. Most marriages were arranged and involved dowry, and husbands were in most cases substantially older than wives.

\section{Perceptions about marriage rituals and dowry}

A common theme in our discussions on marriage change and dowry was the sharp awareness of dowry as a relatively recent phenomenon with strongly negative implications for women's bargaining position in the marriage process. Intergenerational comparisons within the same family 
typically showed that while the grandmother was married with pon (brideprice), the mother married with little or no transaction, and the daughters are getting married with dowry. Rini's grandmother gave detailed descriptions of the jewelry she was adorned with and the wedding dinner hosted by the groom's father: They paid pon (brideprice) for me. They gave Tk.120 as pon. My father received everything-money, jewelry-from the groom's house. First the groom's family provided food for the logon (pre-wedding ceremony). My family only cooked khir (rice pudding). Nowadays, the girl has to bring money and everything from her father's house. The groom's family may say if you are not going to feed us a full meal with rice (and accompaniments) at the wedding, then leave her at her father's house. If we don't pay the "demand", we will have to keep our daughter in the house forever. Back then there were fewer girls. People used to fight over them. My marriage was stalled for Tk.120 pon for one year. Even then I wasn't married off. First they would have to give jewelry, then Tk. 120 pon, and only then they would get me married.

In her contrasts between then and now, Rini's grandmother describes a generational decline in women's bargaining position in the marriage market, reflected in the transformation of marriage transactions from brideprice to dowry, as well as changes in rituals and practices of marriage that suggest women were more highly valued in the past. While some of her retelling may be influenced by nostalgia, she also indicates that the relative status of women in the past was a function of their scarcity, as many demographers have suggested (Rao 1993a; Caldwell, Reddy and Caldwell 1983; Amin and Cain 1997).

One of the wider implications of rising demands for dowry is that the practice has repercussions even for families who are not obliged to pay dowry, since the groom and his family are likely to make other demands. Because the rising practice of dowry sets expectations of men's entitlement, feelings of unmet entitlement demands may surface later and in other ways. This poses a particular dilemma for those parents who are morally opposed to dowry for religious reasons (dowry is not approved in Islamic scriptures). In addition, because dowry demands are the norm, men who do not demand dowry may generate suspicion that there is something wrong with them. The fear is that a marriage without dowry exposes a bride to other risks. A father says, "If a dowry is set (and paid at marriage) you might get away with paying less; with no demand made, you might end up paying much more later." A young respondent gave a concrete example: "A cousin sister of mine got married. The boy is a teacher in high school. They wouldn't take anything. Later, he was going to get a government job and wanted money (for bribes); otherwise he threatened to leave the girl. So the money had to be given."

Thus, onerous as the burden of dowry is for parents, the more far-reaching implication of rising dowry demands in the community relates to the kind of entitlement it implies for grooms. In this environment of high expectations of male entitlements at marriage, it is considered best to settle the matter up front by paying a hefty dowry at marriage.

This notion of settling up front is one of several reasons that families give for paying dowry. While a girl's family pays dowry under duress, they do so with a view to their daughter's future welfare. Families cite two potential benefits for a girl who brings a bigger dowry: first, if her husband chooses to invest the dowry in the new household, payment can result in a better standard of living for the daughter. Cash dowry is particularly helpful for providing capital in a new business 
venture. A second kind of benefit can accrue in joint households where there is competition between brothers' wives. The wife who brings a bigger dowry enjoys higher status.

\section{The process of finding a spouse}

Our case studies also suggest that specific codes of conduct regarding marriage negotiations underlie much of the disadvantage that brides face in the process. While both the bride and the groom have to be strategic in how they go about finding a marriage partner, the bride cannot be too assertive since marriage proposals initiated by a girl's family are unusual. The bride is also disadvantaged because her family is often given very little time to consider a proposal or to find out about the groom. Rules related to considering proposals of marriage are much more strongly influenced by the preferences of the groom. Girls' families are not free to leave a marriage proposal pending: when a matchmaker comes with a proposal, a decision has to be given quickly, usually within three weeks. Parents are hesitant about rejecting a proposal because a girl who has rejected a suitor is usually at higher risk of suffering a reprisal from the rejected party. Even though a girl's parents have little control over marriage negotiations, they are anxious about losing time because of the much greater premium on a girl's young age, whereas young age for boys is actually a disadvantage. There are also fears related to the control of a girl's sexuality, whether because she may make an unsuitable match of her own choice or simply because of malicious gossip that is often circulated about young girls of marriageable age. Two examples of marriage strategies are described below:

Moroni is a well-educated 17-year-old girl who ended up divorced because of a bad marriage decision, possibly because of poor strategic planning by her parents. She is the first child of a reasonably well-off family who was married to a man more than 20 years older. Her father went to see his house and liked it. The groom visited Moroni's house several times before the marriage but always at night. A couple of months before her Metric (10th grade) examination, Moroni was married to him at considerable expense: a total of Tk.45,000 according to her mother. Her parents gave her jewelry and distributed new clothes to her in-law's family. The marriage, however, lasted only 18 days as the girl reportedly "discovered" that her husband had a disability (what she described as a withered arm). Apparently he had previously concealed the condition from her and her family by wearing full-sleeved shirts. To add insult to injury, the groom did not keep his promise of paying for the bride's exam fees and allowing her to complete her Metric.

Jamila's parents were better strategists. Thirteen-year-old Jamila was married off while she was in class six. Although she maintains that she dropped out of school because she was no longer interested in studying, in fact her parents were in the middle of a marriage negotiation when she left school. A previous attempt had been made to marry her into a fairly rich and well-established household. But the groom's family had demanded a high dowry of Tk.25,000, primarily because Jamila has a very dark complexion, and possibly because they were of higher social status than Jamila's parents. When that negotiation failed, her parents arranged for her to marry Towfiq, a neighborhood boy who had a good reputation as a hard worker and as a decent, responsible person with no bad habits. The dowry was settled at Tk.7,500. Towfiq had little education and no land, and 
clearly the marriage would mean an improvement in his social status. Jamila's mother explained that because her sons have set up their own households, they need men to help on their land and in their shop. Towfiq was an appropriate choice for this reason as well as for the fact that he would "respect" them and keep Jamila happy. Our first interview with Jamila took place before this marriage was arranged. At the time, she described her ideal husband as someone who was educated and preferably a businessman. In the second interview, both mother and daughter stated that they had found a "good" groom, this time emphasizing Towfiq's ability to work tirelessly, good character, and lack of bad habits.

\section{The importance of gossip: "The village talks"}

Gossip appears to play a powerful role in marriage decisions in a number of ways. First, parents marry daughters off early because an unmarried, post-pubescent girl is often the subject of gossip. In this regard gossip is an important way for society to control the sexual purity of girls, and fear of malicious gossip is often a reason for arranging very early marriages for girls who are attractive and enjoy the attention of boys.

Some of our cases even suggest that starting a potentially damaging rumor of a girl's romantic involvement with an undesirable groom is often a strategy for weakening the position of the girl's parents. In several cases parents agreed to a marriage proposal under duress and out of fear of the damning rumors and gossip. In Salima's case, her husband was adamant about marrying her and would foil any attempt by other interested parties to propose, usually by spreading rumors and gossip. Finally, Salima's father reluctantly got her married while she was in class 9.

In Deena's case there was the fear of rumors that she was having an affair with her cousin. Deena's father paid for her cousin's education as her potential groom and promised him a job. Even though the bride and groom were eager to marry, the parties could not come to an agreement about dowry. When the negotiations fell through, a rumor began that the two cousins were having premarital relations. Fear of the damaging effects of this rumor led Deena's parents to accept the first marriage proposal that came along for her at the age of 13.

Fear of gossip prompts some parents to marry off their daughters within the natal village so that they can look out for their well-being. We met some families who chose to marry their daughters to men who lived close by so that local gossip would ensure they were informed about their daughters' welfare. On the other hand, some families consider close involvement in a married daughter's life as being meddlesome, leading to complications in their relationship with the husband's family. Parents who do not want to be involved in the everyday lives of their daughters usually decide to marry them to grooms from distant villages. Fourteen-year-old Merina thought she was married at a young age to a man in a distant village because of her parents' fear of gossip. When asked why her parents married her off early she said, "For no (good) reason, and only because the people in the village disturbed me. The boys in the village don't let you go to school. They sit by the road. They married me for fear of that." 


\section{Ideal MARriage AND Constrained Agency}

Standards of propriety make it difficult to elicit responses about ideal characteristics of grooms from girls or their families, even though conversations about brides' characteristics (and their evaluation in terms of dowry costs) are frequently held openly without regard to how girls may be affected by them. When they were asked to state preferences, girls described an ideal husband in terms of his lifestyle rather than more personal characteristics such as good humor or good looks. For example, a respondent may say she would like to marry someone in a non-agricultural profession, presumably because the wife of a farmer has many demands on her time. Educated girls tend to mention education as a desirable characteristic but in language that hints at a more comfortable lifestyle because of vocations and housing that educated families can afford.

It is rare for a girl to say she wishes to marry for love, and as Amin and Cain (1997) discuss this is probably because such marriages usually have little or no parental support. Girls go along with marriage choices made for them by their parents in the hope of ensuring their support for the marriage and in the event that the marriage breaks down. When parents choose a spouse, a substantial responsibility falls on them to ensure the marriage succeeds. Through parental support, girls also assume they will receive the support of the community in their marriage.

Most of our respondents stated that they wanted to get married late, if possible after completing tenth grade at age 16 or 17 . However, 20 is considered a late age for girls to marry, while 25 is the preferred age for the groom. Thus even though girls are motivated to marry late, the normative rules limit the extent to which they can imagine delaying marriage. Similarly, our conversations revealed that girls would like to be married within the natal village so as to remain in close contact with their parents. However, the societal ideal and usually parents' preference is for girls to marry someone outside the natal village. Although living close by facilitates communication and response during crises, several parents held that being married outside of the village will ensure a more stable marriage. The bride's parents are thus removed from household disputes and do not witness accusations and insults, all of which helps in maintaining the marriage.

\section{Deviating from ideals}

One important way to avoid paying dowry or to pay substantially less is for a girl to marry a man who is considerably older than she is. Other strategies for lower dowry are to become a second wife or to marry someone considerably poorer. One of our respondents married a man 27 years older than she when she was 16 and still in school. Her parents paid no dowry for her marriage.

Jamila's marriage, described earlier, is another example of how the choice of marriage partner may fall short of the ideal. Because Jamila is dark skinned and not considered good looking, her family agreed to a marriage proposal from a groom of lesser status who was willing to marry her for a substantially lower dowry than was being requested by a person of equal status to her family. The groom was reputed to be hard-working, and Jamila's mother assumed that because they lived close by and were of inferior status, they would treat her daughter with more respect.

Another strategy used to save on dowry is to marry within the family. Especially if there is a future opportunity to inherit property, the immediate costs of dowry decline or dowry is waived. For 
example, Razia was married to her mother's sister's son. There was no exchange of dowry but there was the expectation of gaining property left by a grandfather. This strategy is also used by parents who have no sons and want their property to remain within the family. For example, 14-year-old Sabina's parents married her without dowry to her mother's brother's son so that the property would remain within the family. In Sabina's words, "Not just education, nothing was considered when the marriage was arranged. I have no brothers. That's why my mother has married me to her brother's son. Otherwise who will eat from all this land?"

\section{Educational Attainment and MARriage Strategies}

The effect of a daughter's education on the timing and quality of her marriage is in large part determined by her family's financial circumstances and social background. A poor family may choose a groom who has less education than their daughter, because a better-educated groom would demand a dowry that they cannot afford. They choose to focus on qualities other than education that would enable the couple to build a good home. Jamila's mother reflects this sentiment: "Money is needed to get a good groom. A woman like me can't give that. I have wishes (but) there's no point having big wishes. So I'll marry her off to a rickshaw puller. The boy's common sense and habits have to be good." Salima's father responded to a question on why he chose a groom with fifth grade education when her daughter had studied to class 8: "He has property (land) so she can eat coarse rice and wear coarse clothes at the least. I saw these and gave her in marriage to him."

The strategy of choosing a less-educated groom is a relatively new one. A more typical, and still preferred, custom is to select a groom who is more highly educated than the bride - a custom that is documented in national-level data. Whereas in the past women were invariably less educated than their husbands, the youngest women in the most recent cohorts of the Demographic and Health Survey are more likely to report being better educated than their husbands (World Bank 2008).

There are thresholds for education that seem to be important. Completing tenth grade and successfully passing the Metric examination appears to have particular significance in rural Bangladesh for both girls and boys. On the one hand, these examinations are very difficult to complete and few boys and fewer girls are successful; on the other hand, certificates are critical for securing most forms of paid employment. Marriage arrangements are further complicated by the fact that once a girl becomes a matriculate, it is not fitting for her to marry a less-educated boy. Our interviews suggest that the dowry required for a matriculate daughter is higher on average because the number of grooms with an appropriate level of education is limited and matriculate boys have higher dowry demands. Some families prefer not to be confined to this more restricted (albeit higherquality) set of potential grooms and decide to marry their daughter off before she becomes a matriculate. Salima's mother explained the family's position regarding her daughter's marriage: "If my daughter had passed Metric, I wouldn't have married her off to a boy who has passed his class 5 . Then I would need an educated boy. That's why I married her off quickly. Less money was needed."

On the other hand, families who are relatively well-off, better educated, and have some status within the community can seek to further their daughter's education while being selective about the characteristics of the groom. When asked about any differences in the proposals she now receives 
after completing her matriculation, Poppy, a girl from such a family, responded, 'Earlier I'd get proposals from class 5/ class 8 graduates. Would they dare to come now? Take for instance Ayub, his son hasn't passed his Metric but they have money. They had given a proposal. Will they dare to talk of marriage now? They have money, but no education. Let's say if someone has passed his Metric and is a big businessman, then my parents would give. My father likes government officers. Businessmen also hold weight." Investments in a daughter's education are further constrained by the fact that even if a potential husband is highly educated, prevailing conditions in the job market make it less likely that he will get a job, limiting the prospect that a daughter will have a better future in his household. In this sense, for the parents, paying a large dowry for an educated groom has no returns.

We found some rare examples in which educated men married educated women with good jobs without requiring dowry. These examples are rare because of the low probability that higher education will lead to gainful employment. Thus only parents who view a daughter's marriage prospects as bleak will take the chance of having her pursue higher education. An educated girl who is able to gain employment is an asset, but this usually comes into play only if some other factor compromises her prospects for marriage. In the case of Nargis and Julekha, dark complexion is the compromising attribute.

Nargis's mother reflected: "Parents of beautiful girls have nothing to worry about. They get married well. And if somehow the girl is dark then there's trouble. It's difficult to marry the girl off. A lot of demands are asked for. I'm really worried about Nargis. They're asking for Tk. 30,000 for her. How will we live if we pay so much? Let her study. If she can pass her Metric and get a job somewhere then she can get married herself."

Similarly, Julekha's mother, whose 14-year-old daughter is studying in class 8, said: "I'll put her in Metro (police) or nursing. Because my father married me off, I didn't get peace; neither did they. Let's see if I can do something for them. My daughter is dark. If she's educated it'll come in handy. Or someone may be interested in marrying her."

These two quotations also reveal two important facts, namely that the amount of dowry increases with dark complexion; and education, specifically when it leads to employment, becomes a viable alternative for girls unable to pay large sums of dowry. In any event, a greater premium is generally placed on good looks than on returns to education in the marriage market. Salima gave the following response to a question on what characteristics are related to dowry: "Yes, one has to give more dowry with time. Let's say a girl has studied quite a lot. She's a little dark and her father has nothing. Then more dowry has to be given. If one studies, too much dowry doesn't have to be given. Maybe if the groom's family doesn't agree to the marriage. Then the girl's father has to give dowry... also if the girl becomes too old."

\section{Secondary school scholarships, higher education, and marriage}

The headmistress of a local secondary school provided insight into the link between education and marriage in the context of incentive programs: "Parents are enrolling their girls here but before a year or two has passed, they have got a groom for her. Previously when there was no such incentive program, the parents used to be genuinely interested in educating their daughters. 
Now that the school is free, parents are using the school to keep their girls until they find a groom for her. They will give them to the school until the time they get a good groom in hand. There is no interest in learning anything."

Thus, while incentive programs are leading to increased rates of enrollment in secondary school, a net increase in the years of education attained, and perhaps even some delay in marriage, their success is largely attributable to the fact that the costs of sending girls to school have been substantially reduced. Before such incentive programs were introduced, parents sent girls to school as part of a conscious strategy of investing in their human capital, presumably with a view to improving their marriage prospects. Nowadays, similar levels of education are achieved without the kind of conscious strategizing on the part of parents that occurred in the past.

Opinions and perceptions differ on whether higher levels of daughters' education lead to increased amounts of dowry. Some respondents argued that educated girls need grooms with more education, who in turn require larger dowry. A respondent's aunt, talking about her plans for her own daughter's wedding, said, "I made my daughter pass her Metric. I'll want an IA pass boy for her, then I'll have to give him a Honda motorbike. And say if the girl is not highly educated, she can be married off to a man who drives a rickshaw van, then less dowry is needed. Maybe they'll ask for Tk. 4000-5000. And if I educate my daughter then I can't marry her off to a rickshaw van-puller. More dowry will be needed then. The girl herself will say, 'I've studied, so why will I marry a vanpuller?"”

Other respondents felt that a girl's higher education acts partly as a substitute for a larger dowry. Nasreen's mother noted: "Yes, the topic of education came up at the time of the wedding. The groom's family asked how far the bride had studied. Because she's educated the dowry was less. If she weren't educated a lot of dowry would've been required. Tk. 10-12 thousand would've been demanded. My daughter is good-looking but we would have needed that money, and some other things."

We also encountered cases in which the incentive programs have motivated parents to opt to educate their daughters with a view to improving their quality of life and providing them with better prospects. Deena's father reported: I sent her to school to make her give her exams and become qualified for jobs. If she passes she can do something in the future. She can teach in school or BRAC school. She can only work if she has the qualifications." Understanding the different responses to the interventions may offer important policy insights on ways to ensure further gains from increasing girls' education.

\section{CONCLUSION}

We have examined qualitative data from young women and their family members to explore the interplay between education and marriage choices. The conversations we recorded provide insights on how people exercise agency and the strategies they employ in constrained environments. It is conceptually important to distinguish between two categories of constraints: one related to poverty and another related to the rules of conduct of the habitus. Decisions about dowry are determined by both sets of factors. While poor parents face greater restrictions in their choice of 
marriage partners than the wealthy and make inferior marriage choices on average, it appears that all families are responsive to rising educational opportunities for girls, even if in different ways. Poor families appear to be quick to opt for a less-educated groom to save on dowry. This is most likely to be true if the returns to education in the labor market are perceived to be limited. On the other hand, poor parents who have not yet accumulated requisite dowry amounts will continue educating their daughters, particularly if there is a reasonable expectation that the girl will work and provide her own dowry. This tactic is also linked to the fact that marrying a groom with less education is within the realm of choice of these families. For wealthier families who can afford higher dowry, the decision to continue their daughter's education is more likely to be motivated by the desire to obtain a better-educated, gainfully employed groom. Having access to free education through incentive programs thus gives parents some leeway to exercise their agency in selecting a groom and adjusting the amount of dowry according to how much they can afford to pay.

Education enters into decisions about marriage in indirect ways, and our qualitative research suggests that from the perspective of girls and their families the contribution of higher education to improving marriage prospects is weak at best and relevant only for those who can afford the higher costs and risks that better marriages require. There is some suggestion as well that while education in the past was an indicator of parental investment in child quality and those who educated their daughters did so as a conscious strategy of investment, the subsidized nature of the present education system makes education the default option for girls. It is something they do while they are waiting to get married. From the perspective of parents, since larger numbers of girls are going to school, having an educated daughter may be less of an advantage in the marriage market now than in the past when education was a privilege that only a few enjoyed.

There is no clear evidence that education is either a substitute for or a complement to dowry. Nor does one find much evidence that access to education on a mass scale, with a particular focus on female education, has any positive benefits for individual women in the marriage market, primarily because, relative to other considerations, education does not play an important role in marriage negotiations. Traditional notions of marriage, cultural imperatives of early marriage, and property and welfare interests persist as key determining factors in the marriage decision. School incentive programs provide the opportunity for continued education for girls only until suitable marriage proposals arrive or the money for dowry is saved. The benefits of education are reaped somewhat by default.

Instead, many other considerations come into play. Assessment of other personal characteristics are important - a girl's beauty and skin color most notably — as are the circumstances surrounding the marriage negotiation itself. We have attempted to demonstrate the various ways in which strategic assessments about how potential brides and grooms are placed in the market are key determinants of marriage outcomes, with dowry being a critical aspect of that process. The way in which potential brides, grooms, and their families conduct themselves with regard to advertising positive attributes, and averting or diffusing negative rumors, is also essential in determining the choice of bride or groom. The decision about whether a girl is sent to school appears to be strongly conditioned by her strategic placement in the marriage market. 


\section{NOTES}

1 Age misreporting is common in rural Bangladesh primarily because age is not recorded at the time of birth. There may also be some deliberate exaggeration of age for married girls since 18 is the legal age at marriage.

2 As noted by Lindenbaum (1981) and Amin and Cain (1997) the English word demand is commonly used to refer to dowry demands made by the groom.

\section{REFERENCES}

Amin, Sajeda. 1996. "Female Education and Fertility in Bangladesh: The Influence of Marriage and the Family," in Girl's Schooling, Women's Autonomy and Fertility Change in South Asia. Eds. Roger Jeffery and Alaka Basu, New Delhi, London and Newbury Park: Sage Publications.

Amin, Sajeda and Mead Cain. 1997. "The rise of dowry in Bangladesh," in The Continuing Demographic Transition. Eds. Gavin W. Jones, John C. Caldwell, Robert M. Douglas, and Rennie M. D’Souza, Oxford: Clarendon Press. Pp. 290-306.

Amin, Sajeda and Cynthia B. Lloyd. 2002. "Women's Lives and Rapid Fertility Decline: Some Lessons from Bangladesh and Egypt." Population Research and Policy Review 21(4): 275317.

Amin, Sajeda, Simeen Mahmud, and Lopita Huq. 2002. "Kishori Abhijan: Baseline Survey Report on Rural Adolescents in Bangladesh." Dhaka: Ministry of Women and Children Affairs, Government of Bangladesh (Supported by UNICEF, Bangladesh).

Behrman, Jere, Andrew Foster, Mark Rosenzweig, and P. Vashishtha. 1999. "Women's schooling, home teaching, and economic growth." Journal of Political Economy 107(4): 682-714.

Caldwell, John, P.H. Reddy, and Pat Caldwell (1983). "The Causes of Marriage Change in South India," Population Studies 37: 343-361.

Edlund, Lena. 2000. "The Marriage Squeeze Interpretation of Dowry Inflation: Comment" Journal of Political Economy 108(6): 1327-1333.

Hallman, Kelly. 2000. "Mother-father resources, marriage payments, and girl-boy health in rural Bangladesh." Unpublished manuscript. Washington, DC: International Food Policy Research Institute.

Jejeebhoy, Shireen. 1995. Women's Education, Autonomy and Reproductive Behaviour: Experience From Developing Countries. Oxford: Clarendon Press. 
Kabeer, Naila. 2001. "'Rational Fools' or 'Cultural Dopes'? Stories of structure and agency in the social sciences." Bangladeshi Women Workers and Labour Market Decisions: The Power to Choose. Dhaka, University Press Limited.

Lindenbaum, Shirley. 1981. "Implications for women of changing marriage transactions in Bangladesh," Studies in Family Planning 12(11): 394-401.

Mahmud, Simeen and Sajeda Amin. 2006. "Girls' schooling and marriage in rural Bangladesh," in Research on the Sociology of Education, Volume 15: Children's Lives and Schooling across Societies. Eds. Emily Hannum and Bruce Fuller. Boston: JAI Elsevier/Science. Pp. 71-99.

Mason, Karen Oppenheim. 1984. The Status of Women: A Review of its Relationships to Fertility and Mortality. New York: The Rockefeller Foundation.

National Research Council (NRC). 2005. Growing Up Global: the Changing Transitions to Adulthood in Developing Countries. Panel on Transitions to Adulthood in Developing Countries. Committee on Population, National Research Council and Institute of Medicine. Washington DC: The National Academy Press.

Rao, Vijayendra. 1993a. "Dowry 'inflation' in rural India: A statistical investigation." Population Studies 47(2): 283-293.

- 1993b. "The rising price of husbands: A hedonic analysis of dowry increases in rural India." Journal of Political Economy 101(4): 666-677.

Sathar, Zeba. 1996. "Women's schooling and autonomy as factors in fertility change in Pakistan: some empirical evidence," in Girls' Schooling: Women's Autonomy and Fertility Change in South Asia. Eds. Roger Jeffery and Alaka Basu, New Delhi: Sage Publications.

Schuler, Sidney Ruth, Lisa M. Bates, Farzana Islam, and Md. Khairul Islam. 2006. “The timing of marriage and childbearing among rural families in Bangladesh: Choosing between competing risks," Social Science \& Medicine 62: 2826-2837.

Sharma, Ursula. 1980. Women, Work and Property in North-West India. London: Tavistock Publications.

World Bank. 2008. "Whispers to Voices: Gender and Social Transformation in Bangladesh." Bangladesh Development Series Paper No. 22, South Asia Sustainable Development Department. Dhaka: The World Bank. 


\section{Poverty, Gender, and Youth Working Papers}

If still in print, single copies of up to three working papers from 1989 through 2003 are available free of charge.

Beginning with the 2004 issues, working papers are no longer available in print format. Instead they are distributed electronically. As each new paper is completed, subscribers are notified by e-mail and a link to the paper is provided.

To subscribe to the Poverty, Gender, and Youth working paper e-mail notification list, or to obtain back issues from 1989 to 2003, please send your request to pgywp@ popcouncil.org.

PDFs of recent issues are available at www.popcouncil.org/publications/wp/index.html

2008

12

Sajeda Amin and Lopita Huq, "Marriage considerations in sending girls to school in Bangladesh: Some qualitative evidence."

11 S. Chandrasekhar and Abhiroop Mukhopadhyay, "Multiple dimensions of urban well-being: Evidence from India"

10 Sajeda Amin and Luciana Suran, "Terms of marriage and time-use patterns of young wives: Evidence from rural Bangladesh."

9 John Bongaarts, Thomas Buettner, Gerhard Heilig, and François Pelletier, "Has the HIV epidemic peaked?"

8 Barbara S. Mensch, Paul C. Hewett, Richard Gregory, and Stephane Helleringer, "Sexual behavior and STI/HIV status among adolescents in rural Malawi: An evaluation of the effect of interview mode on reporting."

7 John Bongaarts, "Fertility transitions in developing countries: Progress or stagnation?"
2007

6 Cynthia B. Lloyd, "The role of schools in promoting sexual and reproductive health among adolescents in developing countries."

5 Ann Biddlecom, Richard Gregory, Cynthia B. Lloyd, and Barbara S. Mensch, "Premarital sex and schooling transitions in four subSaharan African countries."

4 Sajeda Amin, John B. Casterline, and Laura Spess, "Poverty and fertility: Evidence and agenda."

3 Bussarawan Teerawichitchainan and James F. Phillips, "Ethnic differentials in parental health seeking for childhood illness in Vietnam."

2 Zachary Zimmer, Kim Korinek, John Knodel, and Napaporn Chayovan, "Support by migrants to their elderly parents in rural Cambodia and Thailand: A comparative study."

1 Sharon Ghuman and Cynthia B. Lloyd, "Teacher absence as a factor in gender inequalities in access to primary schooling in rural Pakistan.” 


\section{Policy Research Division working papers}

2006

219 Cynthia B. Lloyd and Barbara S. Mensch, "Marriage and childbirth as factors in school exit: An analysis of DHS data from sub-Saharan Africa."

218 Ayaga A. Bawah, James F. Phillips, Martin Adjuik, Maya VaughanSmith, Bruce MacLeod, and Fred N. Binka, "The impact of immunization on the association between poverty and child survival: Evidence from Kassena-Nankana District of northern Ghana."

217 Zachary Zimmer, "Poverty, wealth inequality, and health among older adults in rural Cambodia."

216 John Bongaarts, "Late marriage and the HIV epidemic in sub-Saharan Africa."

209 Cynthia B. Lloyd, Cem Mete, and Monica J. Grant, "The implications of changing educational and family circumstances for children's grade progression in rural Pakistan: 19972004.”

213 Paul Demeny and Geoffrey McNicoll, "The political demography of the world system, 2000-2050.”

212 Monica Grant and Kelly Hallman, "Pregnancy-related school dropout and prior school performance in South Africa."

211 Kelly Hallman, Sara Peracca, Jennifer Catino, and Marta Julia Ruiz, "Multiple disadvantages of Mayan females: The effect of gender, ethnicity, poverty, and residence on education in Guatemala."

210 Geoffrey McNicoll, "Policy lessons of the East Asian demographic transition."

215 John Bongaarts, "How long will we live?"

214 Zachary Zimmer, Toshiko Kaneda, and Laura Spess, "Urban versus rural mortality among older adults in China." 